\title{
OPTIMÁLIS NEURÁLIS HÁLÓZAT KIVÁLASZTÁSA BAYES-BECSLÉS SEGİTSÉGÉVEL
}

\author{
Kondics Milán ${ }^{a}$, Szekeres Béla János ${ }^{b^{*}}$ \\ a ELTE Informatikai, Kar, Programtervezó informatikus MSc, 1. évf. \\ b ELTE Informatikai, Kar, Numerikus Analízis Tanszék, egyetemi adjunktus
}

\begin{abstract}
ABSZTRAKT
Ezen munkánkban célunk, hogy neurális hálózatokra alkalmazva a Bayes-becslést az a posteriori becslések során a különbözô modellek közül kiválasszuk a tanító adatoknak legjobban megfelelőt. Mindehhez egy sokdimenziós integrál kiszámítása szükséges, amely a hagyományos Monte-Carlo módszerekkel is nehéz feladat; erre a célra a beágyazott mintavételezés (nested sampling) algoritmust alkalmazzuk, és a számítások járulékos eredményeként kapjuk meg a betanított hálózatot a hiperparaméterek terében is bolyongást végezve. Továbbá rámutatunk arra, hogyan lehet ötvözni a gradiens visszaterjesztéses és a véletlen bolyongásos tanítást hibrid hálózatokat nyerve.
\end{abstract}

Kulcsszavak: neurális hálózat, nested-sampling, Bayes-tétel

\section{Bevezetés}

A gépi tanulás és a mesterséges intelligencia a számítástudomány sokak által kutatott területe modern világunkban [1]. A tudományos fantasztikus irodalom mellett számtalan valódi alkalmazása létezik, alkalmazzák például beszéd,- arcfelismerésre, vagy önvezetô jármúveknél [2]. A múlt század vége felé merült fel a gondolat biológiai alapokon múködő számoló rendszerek létrehozására azzal a céllal, hogy megfigyelt mintákból vonjunk le tanulságot. De mit jelent tanulni? A neuronjaink tanulnak jelen ismereteink szerint; csoportokba szerveződnek, elektromos ingerek vezérlik a rendszerüket, úgy hogy a megfigyelt mintákra valamilyen értelemben optimálisan reagáljanak.

Ennek modellezéséhez az első fejezetben a szükséges matematikai eszközöket tekintjük át. A második fejezetben ismertetjük az alkalmazott algoritmust, melynek előnye, hogy neurális hálózatokra alkalmazva a Bayes-becslést [3] az a posteriori (utólagos) becslések során a különbözô modellek közül kiválaszthatjuk a tanító adatoknak leginkább megfelelôt. Mindehhez egy sokdimenziós integrál kiszámítása szükséges, ez hagyományos Monte-Carlo módszerekkel nem megoldható, ezért beágyazott mintavételezést [4] alkalmazzuk. A módszer bár nem új, az újszerüségét alkalmazásának módja adja, pontosabban, hogy az optimalitást jellemző mérőszám meghatározására fókuszálunk, illetve a hálózat kimeneti rétegét nem véletlen bolyongás segítségével, hanem Tikhonov-regresszióval [5] tanítjuk. Célunk, hogy a szakirodalomban fellelhetô módszerek többségével ellentétben a hiperparaméterek terében is bolyongva hasonlítsunk össze különböző hibrid neurális hálózatokat e mérôszám segítségével. Egy tesztfeladaton megmutatjuk, hogyan vizsgálható egyszerúen a segítségével a túlillesztés problémája. Numerikus szimulációkkal támasztjuk alá eredményeinket.

\section{Felhasznált matematikai ismeretek}

A neurális hálózatot irányított gráfként képzeljük el [2]. Tegyük fel, hogy balról jobbra haladnak az élek a csúcsok között, továbbá oszlopokba rendezzük a csúcsokat, ezeket az oszlopokat rétegeknek nevezzük. Az egyes rétegek között nem feltétlen fut az összes csúcs között él. A balszélsô csúcsokat

(C) ELTE, Informatikai Kar, Savaria Múszaki Intézet, 2021

*Kapcsolattartó: Szekeres Béla János, szekeres@inf.elte.hu https://doi.org/10.37775/EIS.2021.1.5 


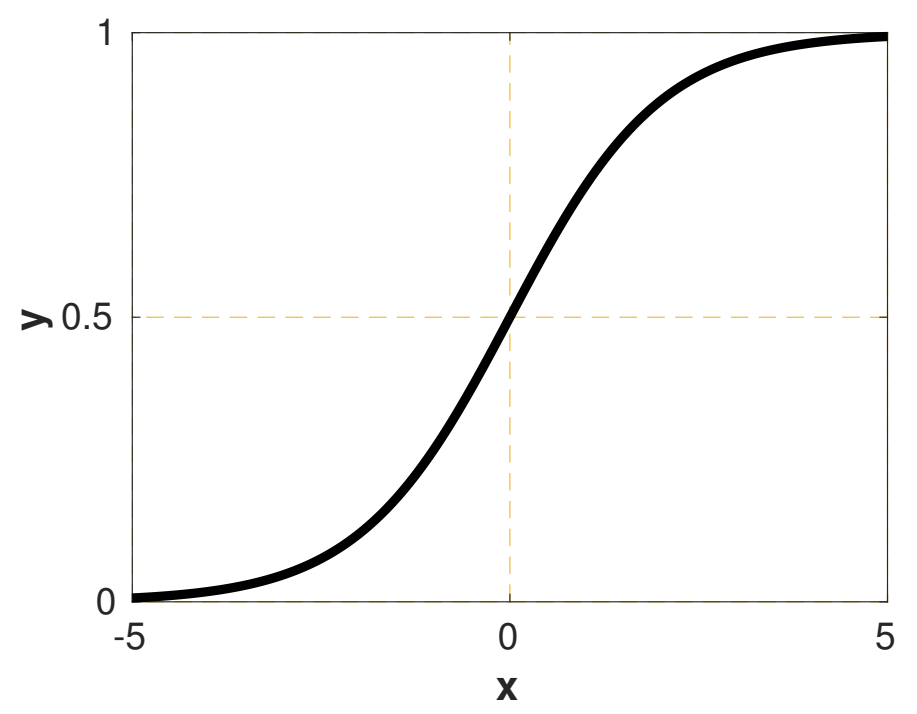

1. ábra: A szigmoid függvény grafikonja

nevezzük bemeneti csúcsoknak, a jobbszélsóket pedig kimenetieknek. A gráf csúcsait neuronoknak nevezzük. Az élek súlyokkal rendelkeznek. A gráf összefüggó, nincs benne kör - a hálózatot ekkor előrecsatoltnak nevezzük - többszörös él, továbbá mindegyik kimeneti neuron elérhető valamely bemenetiből.

\subsection{Többrétegư elôrecsatolt hálózatok}

Legyenek adottak $\alpha, \beta>0$ valós számok. A hálózatban legyen $N$ darab kimenô neuron, $L$ darab bemenő, továbbá $M$ darab $(\mathbf{x}, \mathbf{t})$ tanítóminta-párunk, ahol $\mathbf{x} \in \mathbb{R}^{L}$ bemeneti,- illetve $\mathbf{t} \in \mathbb{R}^{N}$ célvektorok. A hálózatunknak legyen $W$ darab éle. Az éleken az összes súlyok vektorát jelöljük $\mathbf{w} \in \mathbb{R}^{W}$-vel. Legyen adott továbbá az $f_{j}: \mathbb{R} \rightarrow \mathbb{R}$ a $j$ indexú nem bemeneti neuron aktivációs függvénye például $f_{j}(a)=\frac{1}{1+\exp (-a)}, f_{j}(a)=\tanh (a) \operatorname{vagy} f_{j}(a)=a$.

Az 1. ábrán láthatjuk az $f_{j}(x)=\frac{1}{1+\exp (-x)}$ szigmoid függvény grafikonját, amely az egyik leggyakrabban alkalmazott aktivációs függvény. A hálózat az agy múködéséhez hasonlóan felfogható úgy, mint elektromos ingerek terjedése. A hálózat gráfjának élein értelmezett súlyok úgy képzelhetôek el, mint az adott élnek megfelelő szinapszis erôssége. Minél nagyobb a súly, annál jobban terjed rajta az inger, valamint minél nagyobb inger ér egy neuront, annál biztosabb az aktivációja, azaz lesz az értéke példánkban 1-hez közeli. Ha túl kicsi inger ér egy neuront, akkor az aktivációs függvény 0-ra állítja a neuron értékét, nem engedve a rajta áthaladó inger továbbterjedését.

\section{A hálózat múködése:}

Ha a $j$ indexú nem bemeneti neuronra az $l$ indexú szülójétól $y_{l}$ nagyságú inger érkezik, és az óket összekötő szinapszis erôssége $w_{j, l}$, továbbá a neuron aktiválásához $w_{j, 0}$ nagyságú küszöbinger szükséges, akkor az összes a neuronra ható inger összegezhetô, mint

$$
a_{j}=\sum_{l \in\{\mathrm{j} \text { öseinek halmaza }\}} w_{j, l} y_{l}+w_{j, 0} .
$$

Az ôt elhagyó hatás pedig $y_{j}=f_{j}\left(a_{j}\right)$ nagyságú. Amennyiben az $l$ index bemeneti csúcsot jelöl, akkor $y_{l}$ a neki megfelelő komponense az aktuális tanítómintapár x bemeneti vektorának. A küszöbinger felfogható úgy, mint egy, a hálózathoz adott extra 0 indexú bemeneti csúcs, amelyet az összes (nem bemeneti) neuronnal összekötünk. Ebből a $j$. csúcsba menő él súlya pedig $w_{j, 0}$, továbbá adott $y_{0}=1$ bemeneti értékkel. 2. és 3. ábrán látható egy ilyen hálózat felépítése. 


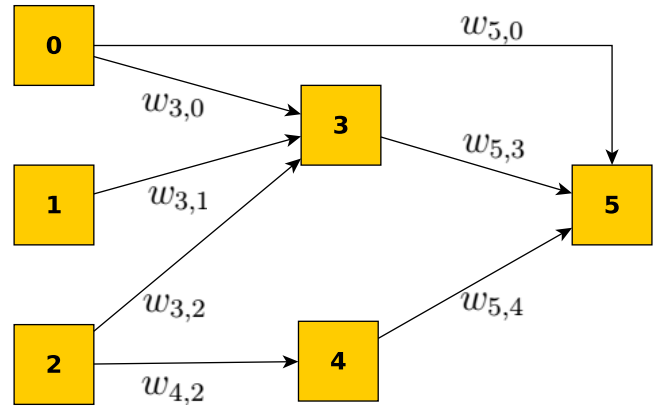

2. ábra: Neurális hálózat két bemeneti neuronnal ( 1 és 2 indexû) és egy kimenetivel (5 indexû)

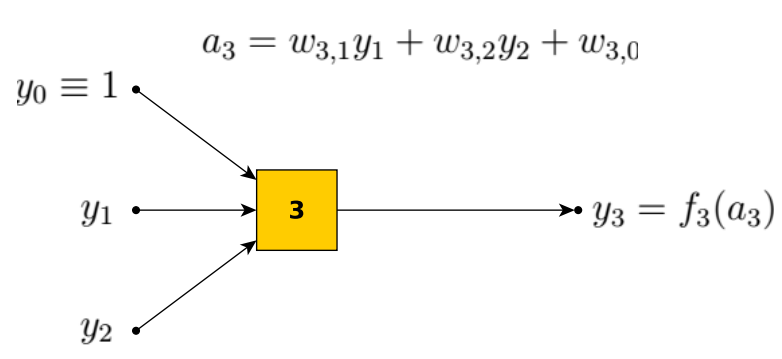

3. ábra: A 3 indexú neuron $y_{3}$ kimenetének számítása. A 0 indexú csúcs felel meg az eltolási paraméternek, értéke $y_{0} \equiv 1$

Az egyes jelölések magyarázata következik, amelyeket használni fogunk még:

- $m$ : az $m$-edik mintát vizsgáljuk épp.

- $y_{i}^{(m)}$ : az $i$-edik neuron kimenete az $m$-edik tanítómintapár bemenetét végigáramoltatva a hálózaton, egyben a $j$-edik neuron bemenete, ha $i$-ból vezet él $j$-be.

- $w_{j, i}$ : az i-edik neuronból a j-edik neuronba mutató élen lévő súly. Minden csúcs bemenetéhez hozzáadunk mesterségesen egy $y_{0}^{(m)}=1$ értéket, a $j$. csúcs esetén $w_{j, 0}$ súllyal.

- $\mathbf{w} \in \mathbb{R}^{W}$ a $w_{j, i}$ súlyokból álló vektor.

- Az m-edik mintapár négyzetes hibája:

$$
\mathcal{E}(m)=\frac{1}{2} \sum_{j=1}^{N}\left(t_{j}^{(m)}-y_{j}^{(m)}\right)^{2},
$$

ahol $t_{j}^{(m)}$ jelöli az $m$-edik tanítómintapárban az elvárt kimenet $j$-edik komponensét, az ennek megfelelő tényleges kimenet pedig $y_{j}^{(m)}$. Az átlagos négyzetes hiba pedig az összes mintapáron ezek átlaga, azaz

$$
\overline{\mathcal{E}}=\frac{1}{M} \sum_{m=1}^{M} \mathcal{E}(m) .
$$

Az átlagos négyzetes középhiba pedig ennek négyzetgyöke. A hálózat tanításának célja, hogy az (1) formulában szereplő hibafüggvényt minimalizáljuk. Erre a célra a Metropolis-algoritmust [6] fogjuk közvetve alkalmazni a gyakorlatban elterjedt gradiens visszaterjesztés helyett. Ennek okát a beágyazott mintavételezési algoritmust tárgyaló részben láthatjuk, mely szerint úgy szeretnénk a hálózat w súlyait véletlenszerúen változtatni, hogy közben csökkentsük a hibát és a súlyok az a priori (jósló) eloszlásból származzanak. A Metropolis-algoritmust a következố részben ismertetjük.

\subsection{A Metropolis-Hastings algoritmus}

Egy példán keresztül vizsgáljuk az algoritmust, amelyet a [6] munkában ismertettek először. A feladat az, hogy generáljunk véletlen mintákat egy képlettel adott eloszlásból, azaz $x \sim \pi(x)$. Legyen például $\pi(x)$ a következő eloszlás:

$$
\pi(x)=\frac{\exp \left(-x^{2}\right)(2+\sin (5 x)+\sin (2 x))}{\int_{-\infty}^{\infty} \exp \left(-x^{2}\right)(2+\sin (5 x)+\sin (2 x)) \mathrm{d} x} .
$$

A probléma az, hogy már a nevezóben szereplő integrált se könnyú kiszámítani. A MetropolisHastings algoritmus lényege, hogy készítünk egy Markov-láncot (jelöljük a tagjait úgy, hogy 
$\left.x_{0}, x_{1}, x_{2}, \ldots\right)$, amelynek a stacionárius eloszlása éppen a kívánt $\pi$ eloszlás. Azaz ha $n \rightarrow \infty$, akkor $x_{n} \sim \pi(x)$ teljesülni fog. Tegyük fel, hogy a Markov-lánc aktuális eleme $x_{n}$; mi $x_{n+1}$-et szeretnénk előállítani. Szükségünk van tehát egy $x^{*}$ jelöltre, ehhez pedig egy $Q\left(x^{*} \mid x_{n}\right)$ jelölt eloszlásra, ami feltételesen függ az aktuális $x_{n}$ állapottól. Egy lehetséges klasszikus választás a jelölt eloszlásra egy $x_{n}$-re centrált normális eloszlás, azaz

$$
x^{*} \mid x_{n} \sim \mathcal{N}\left(x_{n}, \sigma^{2}\right),
$$

a $\sigma$ értéket „ügyesen” kell megválasztani. Tehát vegyünk egy $x^{*}$ mintát ebból a jelölt eloszlásból, ezt valamilyen $\alpha$ valószínúséggel elfogadjuk, mégpedig:

$$
\alpha=\min \left(1, \frac{\pi\left(x^{*}\right)}{\pi\left(x_{n}\right)} \frac{Q\left(x_{n} \mid x^{*}\right)}{Q\left(x^{*} \mid x_{n}\right)}\right) .
$$

Ez azt fogja eredményezni, hogy a (2) formulában szereplő normalizáló konstanssal nem is kell foglalkozni, mert a $\pi$ eloszlás nevezőjében lévô integrál az elóbbi törtben kiegyszerúsödik. A $Q$ eloszlást kell még jól megválasztani, ha $Q$ szimmetrikus, mint a normális eloszlás esetén, akkor $\frac{Q\left(x_{n} \mid x^{*}\right)}{Q\left(x^{*} \mid x_{n}\right)}=1$. Szimmetrikus $Q$ esetén a módszert Metropolis-algoritmusnak nevezzük.

Ezután generálunk egy 0 és 1 közötti $u$ véletlen számot egyenletes eloszlásból. Amennyiben $u \leq \alpha$, akkor $x^{*}$-ot elfogadjuk $x_{n+1}$-ként, egyébként pedig $x_{n+1}:=x_{n}$. A Metropolis-algoritmus pszeudokódját az 1. algoritmus mutatja be.

\subsection{Bayesi neurális hálózatok}

Ebben a részben a Bayesi neurális hálózatok elméletét ismertetjük a [3] munka alapján. Tekintsünk a továbbiakban elórecsatolt hálózatokat. A cél, hogy a $D=\left\{\mathbf{x}^{(\mathbf{m})}, \mathbf{t}^{(\mathbf{m})}: \mathbf{x}^{(\mathbf{m})} \in \mathbb{R}^{L}, \mathbf{t}^{(\mathbf{m})} \in \mathbb{R}^{N}\right.$ és $\left.1 \leq m \leq M\right\}$ rendelkezésre álló adatokon a hálózaton $\mathbf{w}=\left(w_{1}, \ldots, w_{W}\right)$ optimálásával - $W$ a gráf éleinek száma - minimalizáljuk az összes hibát, azaz az alábbi függvényt.

$$
E_{\beta, D}(\mathbf{w})=\frac{\beta}{2} \sum_{m=1}^{M} \sum_{n=1}^{N}\left(t_{n}^{(m)}-y_{n}\left(\mathbf{x}^{(m)}, \mathbf{w}\right)\right)^{2},
$$

ahol $t_{n}^{(m)}$ jelöli a $\mathbf{t}^{(m)} m$-edik célvektor $n$-edik komponensét.

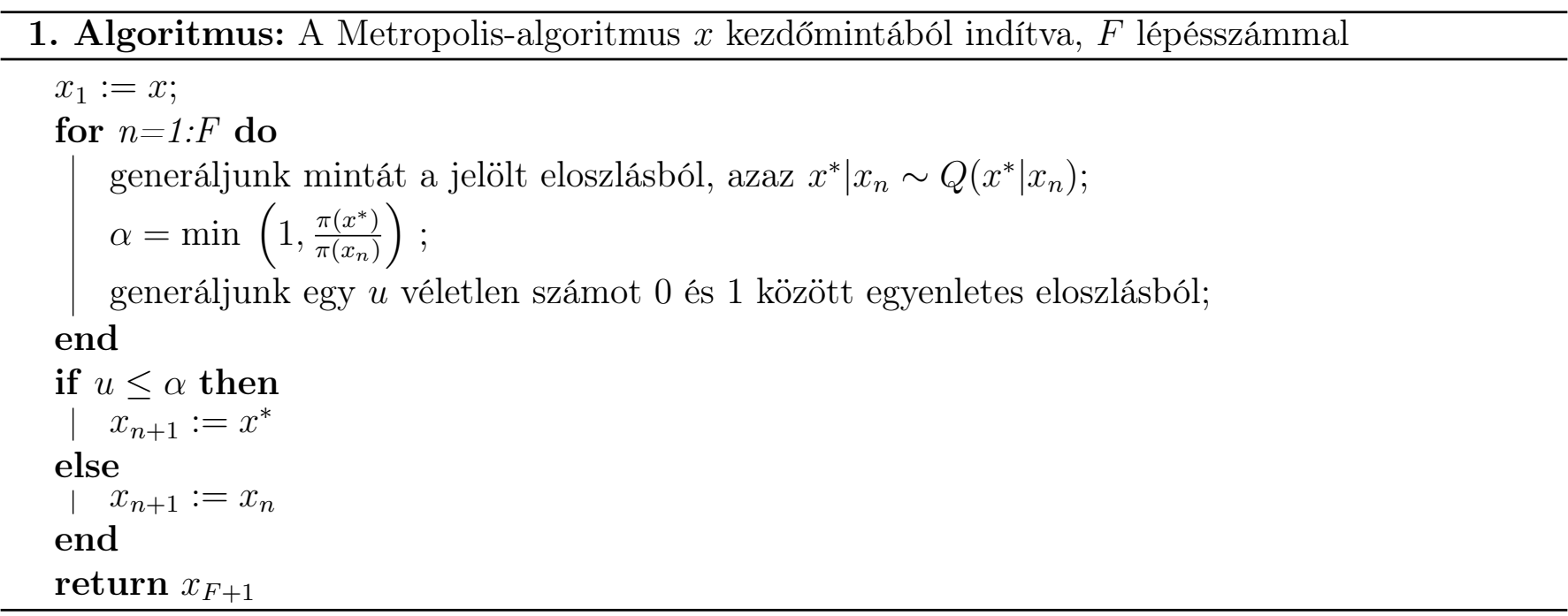


Hozzáadunk $E_{\beta, D}(\mathbf{w})$-hez még egy $E_{\alpha}(\mathbf{w})$ regularizáló tagot is, amely

$$
E_{\alpha}(\mathbf{w})=\frac{\alpha}{2} \sum_{j=1}^{W} w_{j}^{2}
$$

Az $\alpha / \beta$ hányados nagysága azt mutatja meg, hogy mennyire büntetjük a nagy súlyokat a hiba minimalizálásához képest. Az ötlet az, hogy w-re tekintsünk most úgy, mintha valamilyen ismert a priori speciális eloszlásból származó valószínúségi változó volna, majd a Bayes-becslést használva előállíthatjuk az a posteriori eloszlását w-nek. Ami azt jelenti, hogy a tanító adatoknak jobban megfelelő w-t kapunk.

Legyen tehát a súlyok a priori eloszlása 1/ $\alpha$ szórásnégyzetú normális eloszlás, azaz a súlyok együttes sưrúségfüggvénye úgy írható, mint

$$
p(\mathbf{w} \mid \alpha)=\prod_{i=1}^{W} p\left(w_{i} \mid \alpha\right)=\frac{\exp \left(-E_{\alpha}(\mathbf{w})\right)}{(2 \pi)^{W / 2} \alpha^{-W / 2}}
$$

A gráfot leíró modellt jelölje röviden $\mathcal{G}$, tegyük fel továbbá, hogy a tanítás során a $D$ adatok normális eloszlásúak $y_{n}^{(m)}\left(\mathbf{x}^{(m)}, \mathbf{w}\right)(n=1, \ldots, N$ és $m=1, \ldots, M)$ várható értékkel és $1 / \beta$ szórásnégyzettel, azaz írhatjuk hogy

$$
p(D \mid \mathbf{w}, \beta, \mathcal{G})=\prod_{m=1}^{M} \prod_{n=1}^{N} p\left(t_{n}^{(m)} \mid \mathbf{x}^{(m)}, \mathbf{w}, \beta\right)=\frac{1}{(2 \pi)^{M N / 2} \beta^{-M N / 2}} \exp \left(-E_{\beta, D}(\mathbf{t}, \mathbf{w})\right) .
$$

A hálózat klasszikus tanítása során azt a $\mathbf{w}^{*}$ súlyt keressük, melyre $p\left(D \mid \mathbf{w}^{*}, \beta, \mathcal{G}\right) p(\mathbf{w} \mid \alpha, \mathcal{G})$ vagy $p\left(D \mid \mathbf{w}^{*}, \beta, \mathcal{G}\right)$ maximális volt, azaz amely mellett a legnagyobb valószínúséggel figyelhetjük meg a $D$ adatokat. A Bayes-tételt felhasználva viszont azt a w súlyt fogjuk megkeresni, amely a legvalószínúbb a $D$ adatok ismeretében.

Megjegyzés: Folytassuk az alábbi sorozatot:

$$
3,7,11, a_{4}=? .
$$

A legtöbben rávágják, hogy 15 a következő elem. De ide bármilyen $a_{4}=a$ számot írhatnánk igazából, hogyha a sorozat következő tagját egy interpoláló polinommal állítjuk elő (pontosabban fogalmazva, létezik olyan $f$ harmadfokú polinom, amelyre $f(1)=3, f(2)=7, f(3)=11$ és $f(4)=a)$. Mégis, az elsô választ érezzük a helyénvalónak. Belátható a Bayes-tétel és valószínúségszámítási megfontolások segítségével, hogy valóban a 15 a legvalószínúbb válasz. Ez Occam borotvájának elve. Ha több lehetséges magyarázat is létezik egy jó válaszra, akkor a valószínúbbet fogadjuk el. Hogy melyik a legvalószínúbb, azt a Bayes-tétel segítségével határozhatjuk meg.

\section{A Bayes-tétel:}

Jelölje $p(\theta)$ a $\theta$ keresett paraméter a priori eloszlását, mielőtt még látnánk a megfigyelési adatokat. Továbbá, $p(D \mid \theta)$ annak a valószínúsége, hogy a $D$ adatokat figyeljük meg ismerve $\theta$-t. A Bayes-tétel felhasználásával a következóképpen határozhatjuk meg $\theta$ a posteriori eloszlását az adatok ismeretében:

$$
p(\theta \mid D)=\frac{p(D \mid \theta) p(\theta)}{p(D)}
$$

Neurális hálózatokra alkalmazva a súlyok a posteriori eloszlása így

$$
p(\mathbf{w} \mid D, \alpha, \beta, \mathcal{G})=\frac{p(D \mid \mathbf{w}, \beta, \mathcal{G}) p(\mathbf{w} \mid \alpha, \mathcal{G})}{p(D \mid \alpha, \beta, \mathcal{G})}=\frac{p(D \mid \mathbf{w}, \beta, \mathcal{G}) p(\mathbf{w} \mid \alpha, \mathcal{G})}{\int_{\mathbb{R}^{W}} p(D \mid \mathbf{w}, \beta, \mathcal{G}) p(\mathbf{w} \mid \alpha, \mathcal{G}) \mathrm{d} \mathbf{w}}
$$


Azt a $\mathbf{w}^{*}$-t keressük, amelyre ez maximális, azaz az adott feltételek és megfigyelési adatok mellett a legvalószínúbb. Ez rögzített $\alpha, \beta$ hiperparaméterek és $\mathcal{G}$ gráfszerkezet mellett akkor maximális, ha a tört számlálója, $p\left(D \mid \mathbf{w}^{*}, \beta, \mathcal{G}\right) P\left(\mathbf{w}^{*} \mid \alpha, \mathcal{G}\right)$ maximális, a nevezô ugyanis független $\mathbf{w}$-tól. Ez azt jelenti, hogy a hálózat tanítása során éppen a hibát minimalizáló optimális $\mathbf{w}^{*}$ súly a legvalószínúbb.

\section{A hiperparaméterekról:}

Felmerül a kérdés, hogy az $\alpha, \beta$ hiperparamétereket hogyan válasszuk meg, hiszen a (7) formulában ezeket a priori ismertnek tételeztük fel. Két lehetőségünk van:

(a) Felváltva megkeressük az optimális w súlyokat - akár visszaterjesztéses módszerrel, akár véletlen kereséses eljárással - rögzített $\alpha, \beta$ értékek mellett és fordítva, azaz az imént talált w súlyokat rögzítve megkeressük a legjobb $\alpha, \beta$ paramétereket. Ezt iterálva eljuthatunk egy optimális $\mathbf{w}_{\mathrm{opt}}$,

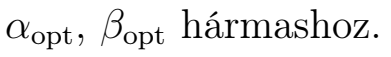

(b) Alkalmazhatjuk a Bayes-tételt $\alpha$ és $\beta$ mentén marginalizálva, azaz

$$
p(\mathbf{w} \mid D, \mathcal{G})=\frac{1}{p(D \mid \mathcal{G})} \int_{0}^{\infty} \int_{0}^{\infty} p(D \mid \mathbf{w}, \beta, \mathcal{G}) p(\mathbf{w} \mid \alpha, \mathcal{G}) p(\alpha) p(\beta) \mathrm{d} \alpha \mathrm{d} \beta,
$$

ahol

$$
p(D \mid \mathcal{G})=\int_{\mathbb{R}^{W}} \int_{0}^{\infty} \int_{0}^{\infty} p(D \mid \mathbf{w}, \beta, \mathcal{G}) p(\mathbf{w} \mid \alpha, \mathcal{G}) p(\alpha) p(\beta) \mathrm{d} \alpha \mathrm{d} \beta \mathrm{d} \mathbf{w}
$$

A gráf szerkezetének megválasztása:

Tegyük fel, hogy rendelkezésünkre állnak a $\mathcal{G}_{1}$ és $\mathcal{G}_{2}$ gráf szerkezetekhez tartozó (9) egyenlőségbeli $p\left(D \mid \mathcal{G}_{1}\right)$ és $p\left(D \mid \mathcal{G}_{2}\right)$ mennyiségek, vagyis hogy mekkora valószínúséggel figyeljük meg a $D$ adatokat az a priori feltételezett két különböző gráf mellett. Nekünk arra volna szükségünk, hogy látva a $D$ adatokat, meghatározzuk az adatoknak legjobban megfelelő gráfot.

Alkalmazva a (9) formulát és a Bayes-tételt összehasonlíthatjuk a két gráf valószínûségét az adatok megismerése után. Amennyiben ugyanolyan valószínúséggel választunk két különböző gráfszerkezetet, meghatározhatjuk az alábbi hányadost.

$$
\begin{aligned}
\frac{p\left(\mathcal{G}_{1} \mid D\right)}{p\left(\mathcal{G}_{2} \mid D\right)} & =\frac{p\left(\mathcal{G}_{1}\right)}{p\left(\mathcal{G}_{2}\right)} \frac{p\left(D \mid \mathcal{G}_{1}\right) / p(D)}{p\left(D \mid \mathcal{G}_{2}\right) / p(D)}= \\
& =\frac{\int_{\mathbb{R}^{W}} \int_{0}^{\infty} \int_{0}^{\infty} p\left(D \mid \mathbf{w}, \beta, \mathcal{G}_{1}\right) p\left(\mathbf{w} \mid \alpha, \mathcal{G}_{1}\right) p(\alpha) p(\beta) \mathrm{d} \alpha \mathrm{d} \beta \mathrm{d} \mathbf{w}}{\int_{\mathbb{R}^{W}} \int_{0}^{\infty} \int_{0}^{\infty} p\left(D \mid \mathbf{w}, \beta, \mathcal{G}_{2}\right) p\left(\mathbf{w} \mid \alpha, \mathcal{G}_{2}\right) p(\alpha) p(\beta) \mathrm{d} \alpha \mathrm{d} \beta \mathrm{d} \mathbf{w}}
\end{aligned}
$$

amely ha nagyobb egynél, akkor a $\mathcal{G}_{1}$ gráf írja le jobban az adatokat. Ezen (9)-beli integrálok még Monte-Carlo integrálással is nehezen számolhatóak, ezért beágyazott mintavételezést alkalmazunk a numerikus approximációhoz és mintegy járulékos eredményként kapjuk meg az optimális w súlyokat és $\alpha, \beta$ hiperparamétereket.

\subsection{A beágyazott mintavételezés}

A feladat a (9) integrál kiszámítása, erre a célra a beágyazott mintavételezést fogjuk alkalmazni, melyet az [4] munka alapján ismertetünk. A feladat egy többdimenziós $\int_{\mathbb{R}^{k}} L(\theta) \pi(\theta) \mathrm{d} \theta$ alakú integrál kiszámítása, $L$-t a továbbiakban likelihood függvénynek nevezzük, $\pi$ pedig valamilyen $k$ dimenziós eloszlás. Legyen $N$ adott, ekkor az eljárás pszeudokódját a 2. algoritmus szemlélteti. 


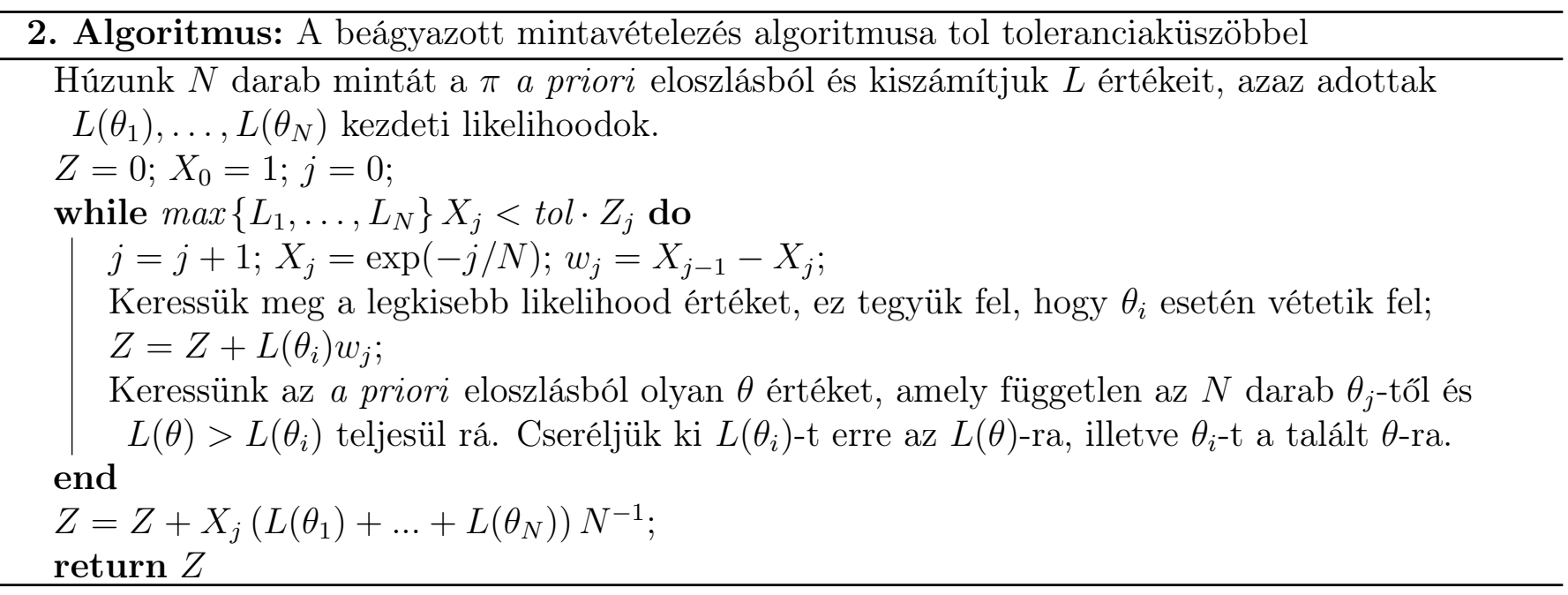

\subsection{Lineáris regresszió a kimeneti rétegen}

Ha olyan egyenletrendszert szeretnénk megoldani, amely több egyenletból áll, mint ismeretlent tartalmaz, azaz az $A \mathbf{x}=\mathbf{b}$ lineáris egyenletrendszer $A \in \mathbb{R}^{n \times m}$ mátrixára $n>m$ teljesül, akkor lehetôségünk van az általánosított inverz segítségével az euklideszi normában legjobban approximáló megoldást előállítanunk az $\tilde{\mathbf{x}}=\left(A^{T} A\right)^{-1} A^{T} \mathbf{b}$ alakban. Az $\tilde{\mathbf{x}}$ minimalizálja a $h(\mathbf{x})=\|A \mathbf{x}-\mathbf{f}\|_{0}^{2}$ függvényt, ahol $\|\cdot\|_{0}$-val az euklideszi normát jelöljük. Előfordulhat, hogy a $g(\mathbf{x})=\|A \mathbf{x}-\mathbf{f}\|_{0}^{2}+\gamma\|\mathbf{x}\|_{0}^{2}$ függvényt szeretnénk minimalizálni, ahol $\gamma \geq 0$. Ezt Tikhonov-regularizáció segítségével tehetjük meg, a minimumhelyet az $\tilde{\mathbf{x}}=\left(A^{T} A+\gamma I\right)^{-1} A^{T} \mathbf{b}$ formulával nyerhetjük [5], ahol $I \in \mathbb{R}^{n \times n}$.

A 4. ábrán látható példában a kimeneti csúcs az 5 indexú, a piros színúek a kimeneti élek, melyek súlyai $w_{5,0}, w_{5,3}$ és $w_{5,4}$. Olyan hálózatokat vizsgáltunk, ahol a kimeneti csúcsok aktivációs függvénye az identitás, így a kimeneti élek súlyait Tikhonov-regularizáció segítségével határozzuk meg, mely so-rán az $\tilde{x}$-et megadó formulába $\gamma=\frac{\alpha}{\beta}$ kerül. Gradiens visszaterjesztést is alkalmazhatunk ezeken az éleken, így építhetünk egy egész előrecsatolt hálót is, a háló többi élét pedig továbbra is véletlen bolyongás segítségével tanítjuk, hibrid hálót nyerve.

\section{A fejlesztett algoritmus}

Ebben a részben ismertetjük a teljes algoritmust. A gyakorlatban a (10) formulában szereplô integrálokat nem szokás kiszámolni, helyettük az $\alpha, \beta$ hiperparaméterek a posteriori eloszlásából következtetnek az optimális $\alpha_{\mathrm{opt}}, \beta_{\mathrm{opt}}$ értékekre, majd gradiens visszaterjesztés segítségével minimalizálják (3) és (4) hibaformulák összegét.

Az a priori eloszlások megválasztása nem egyszerú feladat, az egyszerúség kedvéért noninformatív eloszlást választottunk a [3] munka javaslata alapján: legyenek $\alpha \sim \mathcal{U}\left(0, I_{\alpha}\right), \beta \sim \mathcal{U}\left(0, I_{\beta}\right)$ egyenletes

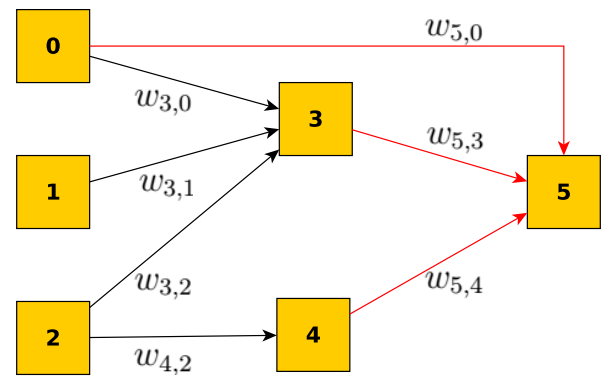

4. ábra: A kimeneti réteg szemléltetése 
eloszlásúak valamilyen $I_{\alpha}$ és $I_{\beta}$ pozitív számokkal. Kiszámítandó tehát a (9)-beli integrál, amelyet jelöljünk $Z$-vel. Ez az integrál $W+2$ dimenziós, ahol $W$ a háló éleinek számát jelöli.

A beágyazott mintavételezés algoritmusában az $L(\mathbf{w}, \alpha, \beta)$ likelihood függvény és a $\pi(\mathbf{w}, \alpha, \beta)$ a priori eloszlás az alábbiak $\alpha \in\left[0, I_{\alpha}\right], \beta \in\left[0, I_{\beta}\right]$ és $\mathbf{w} \in \mathbb{R}^{W}$ esetén.

$$
\begin{gathered}
L(\mathbf{w}, \alpha, \beta)=\left(\frac{\beta}{2 \pi}\right)^{M N / 2} \exp \left(-\frac{\beta}{2} \sum_{m=1}^{M} \sum_{n=1}^{N}\left(t_{n}^{(m)}-y_{n}\left(\mathbf{x}^{(m)}, \mathbf{w}, \alpha, \beta\right)\right)^{2}\right) \text { és } \\
\pi(\mathbf{w}, \alpha, \beta)=\left(\frac{\alpha}{2 \pi}\right)^{W / 2} \frac{\exp \left(-\frac{\alpha}{2} \sum_{j=1}^{W} w_{j}^{2}\right)}{I_{\alpha} I_{\beta}}
\end{gathered}
$$

A (11) formulában a hálózat $y_{n}\left(\mathbf{x}^{(m)}, \mathbf{w}, \alpha, \beta\right)$ kimenetének $\alpha$ és $\beta$ argumentuma arra utal, hogy azt egyértelmúen meghatározza a Tikhonov-regularizáció. A $\pi$ a priori eloszlásunkból úgy generálunk egy $\theta \in \mathbb{R}^{W+2}$ véletlen vektort, hogy veszünk $\alpha \sim \mathcal{U}\left(0, I_{\alpha}\right), \beta \sim \mathcal{U}\left(0, I_{\beta}\right)$ véletlen számokat (ezek lesznek $\theta$ utolsó két komponense), majd generálunk $W$ darab standard normális eloszlású véletlen számot, és ezek mindegyikét megszorozzuk $\alpha^{-1 / 2}$-nel, így normális eloszlásúak lesznek $1 / \alpha$ szórásnégyzettel. Adott $\theta$ helyen $L$ úgy számolható, hogy a hálót kiértékeljük $\theta$ elsô $W$ darab komponensével adott súlyszettel, a kimeneti élek súlyát pedig $\alpha / \beta$ paraméterú Tikhonov-regularizáció segítségével határozzuk meg, melyek $\theta$ utolsó két komponensei. A teljes algoritmust a 3. pszeudokódban foglaltuk össze.

3. Algoritmus: A fejlesztett algoritmus

Legyenek $\mathbb{R}^{W+2} \ni \theta_{j} \sim \pi, j=1, \ldots, N$ véletlen vektorok. $Z:=0$ és $X_{0}=1, f \in \mathbb{R}$

toleranciaküszöb adott az integrálhoz, továbbá $Q$ egy $W+2$ dimenziós jelölt eloszlás és $F \in \mathbb{N}$ fix lépésszám a Metropolis-algoritmushoz, azaz adottak $L\left(\theta_{1}\right), \ldots, L\left(\theta_{N}\right)$ kezdeti likelihoodok.

$Z=0 ; X_{0}=1 ; j=0$;

while $\max \left\{L_{1}, \ldots, L_{N}\right\} X_{j}<\mathrm{tol} \cdot Z_{j}$ do

$j=j+1 ; X_{j}=\exp (-j / N) ; w_{j}=X_{j-1}-X_{j}$;

Keressük meg a legkisebb likelihood értéket, ez tegyük fel, hogy $\theta_{i}$ esetén vétetik fel.

$Z=Z+L\left(\theta_{i}\right) w_{j}$

Legyen $\tilde{\theta}_{0}$ a tárolt $\theta_{j}(j=1, \ldots, N)$ elemek közül véletlenszerú;

for $n=0: F$ do

generáljunk véletlen $\tilde{\theta}^{*}$ mintát a $Q$ jelölt eloszlásból, azaz $\tilde{\theta}^{*} \mid \tilde{\theta}_{n} \sim Q\left(\tilde{\theta}^{*} \mid \tilde{\theta}_{n}\right)$;

számítsuk ki a $\gamma$ elfogadási valószínúséget $\gamma=\min \left(1, \frac{\pi\left(\tilde{\theta}^{*}\right)}{\pi\left(\tilde{\theta}_{n}\right)}\right)$;

generáljunk egy $u \sim \mathcal{U}(0,1)$ véletlen számot;

if $u \leq \gamma$ és $L\left(\tilde{\theta}^{*}\right)>L\left(\theta_{i}\right)$ then

$\tilde{\theta}_{n+1}:=\tilde{\theta}^{*}$

else

$\tilde{\theta}_{n+1}:=\tilde{\theta}_{n}$

end

\section{end}

Cseréljük ki $L\left(\theta_{i}\right)$-t erre az $L\left(\tilde{\theta}_{F+1}\right)$-re, illetve $\theta_{i}$-t a talált $\tilde{\theta}_{F+1}$-re.

$Z=Z+X_{j}\left(L\left(\theta_{1}\right)+\ldots+L\left(\theta_{N}\right)\right) N^{-1}$

return $Z$ 
1. táblázat: A [7] munka 9. táblázatában szereplő $5 \times 2$ keresztvalidáció eredménye

\begin{tabular}{l|cccccccc} 
Módszer & 1. & 2. & 3. & 4. & 5. & 6. & 7. & 8. \\
\hline Átlaghiba [MWh] & 5,426 & 4,561 & 4,572 & 5,399 & 8,487 & 4,561 & 4,563 & 4,656 \\
\hline \hline Módszer & 9. & 10. & 11. & 12. & 13. & 14. & 15. & \\
\hline Átlaghiba [MWh] & 3,861 & 8,221 & 5,556 & 3,779 & 4,128 & 4,087 & 4,211 &
\end{tabular}

\section{Numerikus eredmények}

Választott modellünk témája, egy alapterhelésen múködő, kombinált ciklusú erômú teljes töltésnél mért elektromos kimenetének becslése [7]. Ez egy általános approximációs probléma a gépi tanulás módszereivel, viszont megoldása fontos hatékonysági és gazdasági szempontból egyaránt. A rendszer múködését négy fố paraméter befolyásolja, amelyeket bemeneti változóként használnak az adathalmazban. Ezek az adatok, egy több, mint hat éven át tartó mérési sorozat eredményei, összesen 9568 darab bemeneti-kimeneti adatpárt tartalmaznak, ahol minden mérési adat egy óránkénti átlag, melyet az erômú szenzorai rögzítettek. A bemenô adatok a környezet hômérséklete, a légköri nyomás, a relatív nedvességtartalom, valamint a kiáramló gőznyomás.

A szerzók a különbözô módszereket $5 \times 2$ keresztvalidáció segítségével hasonlították össze, ez azt jelenti, hogy a teljes adathalmazt 5 alkalommal véletlenszerúen két részre osztották, a halmaz egyik felét tanításra használták, a másik felén pedig tesztelték a tanított modellt, majd felcserélték a két halmaz szerepét. Az $5 \times 2$ keresztvalidációban a módszer hatékonyságát a 10 teszthalmazon vett hiba átlaga adja: minél kisebb, annál jobb a módszer. A [7] munkában 15 módszert hasonlítottak össze így a szerzók, az erre vonatkozó eredményeiket láthatjuk az 1. táblázatban.

Az alábbiakban ismertetjük szimulációs eredményeinket. Egy darab rejtett réteggel rendelkező elôrecsatolt hálózatokat hasonlítottunk össze eltérô neuronszámmal a rejtett rétegben, ahol az aktivációhoz a szigmoid függvényt választottuk, valamint a kimeneti rétegen $\alpha / \beta$ paraméterú Tikhonovregularizációt alkalmaztunk. Az adatsor véletlenszerúen kiválasztott felén végeztük a hálók tanítását az előző fejezetben ismertetett algoritmussal, az adatsor másik felén pedig kiértékeltük óket. Ezen eredmények a 2. táblázatban láthatóak, amelyekben a rejtett rétegbeli neuronok számát $R$ jelöli, a tanító halmazon számolt négyzetes középhibát és a validációs hibát pedig $T$ és $V$. A Bayes-faktor a $p\left(\mathcal{G}_{R} \mid D\right) / p\left(\mathcal{G}_{10} \mid D\right)$ kifejezés logaritmusát jelenti (a nagyobb érték a jobb).

\section{Következtetések}

Munkánk során azt vizsgáltuk, hogy neurális hálózatokra alkalmazva a Bayes-becslést az a posteriori becslések során a különbözô modellek közül hogyan válasszuk ki a tanító adatoknak leginkább megfelelôt. Mindehhez egy sokdimenziós integrál kiszámítása szükséges, amelyre a beágyazott mintavételezést alkalmaztuk. Megmutattuk, hogyan lehet ötvözni a gradiens visszaterjesztéses és a véletlen bolyongásos tanítást hibrid hálózatokat nyerve. A módszer hasznosságát numerikus kísérletekkel támasztottuk alá. Szimulációink kimenetét a [7] munka 1. táblázatban látható eredményeivel összehasonlítva azt állíthatjuk, hogy az általunk alkalmazott módszer validálási hibája még a legkevesebb neuronszám esetén is a 15 módszerrel összevetve a 3. legjobb. A Bayes-faktor segítségével azt is meg-

2. táblázat: Szimulációs eredmények $N=100$ hálózattal

\begin{tabular}{l|cccccccccc}
$\mathbf{R}$ & 10 & 20 & 30 & 40 & 50 & 60 & 70 & 80 & 90 & 100 \\
\hline \hline T [MWh] & 3,895 & 3,823 & 3,843 & 3,839 & 3,875 & 3,853 & 3,849 & 3,860 & 3,953 & 3,926 \\
V [MWh] & 4,062 & 4,000 & 4,017 & 3,984 & 4,056 & 4,032 & 3,994 & 4,043 & 4,080 & 4,075 \\
Bayes-faktor & 0,0 & $-41,4$ & 38,3 & 82,4 & $-340,2$ & $-161,0$ & $-67,0$ & $-212,6$ & $-74,2$ & 4,9
\end{tabular}


állapíthatjuk, hogy 40-nél több neuront alkalmazni a rejtett rétegben túlillesztéshez vezet, amelyet alátámaszt, hogy a validációs hibák ennél nagyobb hálózat esetén már nem csökkennek. A legkisebb validációs hibához tartozik a legnagyobb Bayes-faktor, melyet a 40 rejtett rétegbeli neuronnal rendelkezô hálózat esetén figyelhetünk meg, vagyis ez az optimális választás az általunk vizsgált hálózatok közül.

\section{Köszönetnyilvánítás}

A kutatást a 2019-1.3.1-KK-2019-00011 számú projekt támogatta, ami a Nemzeti Kutatási Fejlesztési és Innovációs Alapból biztosított támogatással, a „KOMPETENCIA KÖZPONTOK LEETREHOZÁSA- KUTATÁSI INFRASTRUKTÚRA FEJLESZTÉS” pályázati program finanszírozásában valósult meg. Továbbá ezen munka elkészítése során a Kormányzati Információs Fejlesztési Ügynökség (KIFÜ) szuperszámítógépes infrastruktúráját használtuk.

\section{Irodalomjegyzék}

[1] D.E. Rumelhart, G.E. Hinton, R.J. Williams, Learning representations by back-propagating errors, Nature 323, 1986, pp. 533-536, CrossRef

[2] Horváth G., Altrichter M., Horváth G., Pataki B., Strausz Gy., Takács G., Valyon J., Neurális hálózatok, Budapest, Panem Kiadó, 2006.

[3] C.M. Bishop, Bayesian methods for neural networks, in L. Tarassenko, E. Rolls, D. Sherrington (Eds.), Oxford Lectures on Neural Networks, Oxford University Press., 1995.

[4] J. Skilling, Nested sampling for general Bayesian computation, Bayesian Anal. 1(4), 2006, pp. 833-859, CrossRef

[5] D.L. Phillips, A Technique for the Numerical Solution of Certain Integral Equations of the First Kind, Journal of the ACM 9, 1962, pp. 84-96, CrossRef

[6] W.K. Hastings, Monte Carlo Sampling Methods Using Markov Chains and Their Applications, Biometrika 57, 1970, pp. 99-109, CrossRef

[7] P. Tüfekci, Prediction of full load electrical power output of a base load operated combined cycle power plant using machine learning methods, International Journal of Electrical Power \& Energy Systems 60, 2014, pp. 126-140, CrossRef 